\title{
New socio-economic perspectives on integration in the Americas
}

Intégrations dans les Amériques : nouvelles perspectives socio-économiques Integración regional en las Américas. Nuevas perspectivas socioecononómicas

\section{Christine Zumello and Jean-Baptiste Velut}

\section{(2) OpenEdition}

\section{Journals}

\section{Electronic version}

URL: https://journals.openedition.org/ideas/3031

DOI: 10.4000/ideas.3031

ISSN: 1950-5701

This article is a translation of:

Intégrations dans les Amériques: Nouvelles perspectives socio-économiques - URL : https:// journals.openedition.org/ideas/103 [fr]

\section{Other translation(s):}

Integración en las Américas: nuevas perspectivas socioeconómicas - URL : https:// journals.openedition.org/ideas/3037 [es]

Integrações nas Américas: Novas perspectivas socioeconômicas - URL : https:// journals.openedition.org/ideas/3043 [pt]

\section{Publisher}

Institut des Amériques

\section{Electronic reference}

Christine Zumello and Jean-Baptiste Velut, "New socio-economic perspectives on integration in the Americas", IdeAs [Online], 1 | 2011, Online since 26 July 2018, connection on 19 October 2022. URL: http://journals.openedition.org/ideas/3031 ; DOl: https://doi.org/10.4000/ideas.3031

This text was automatically generated on 19 October 2022

\section{(c) (i) (9)}

Creative Commons - Attribution-NonCommercial-NoDerivatives 4.0 International - CC BY-NC-ND 4.0 https://creativecommons.org/licenses/by-nc-nd/4.0/ 


\title{
New socio-economic perspectives on integration in the Americas
}

\author{
Intégrations dans les Amériques : nouvelles perspectives socio-économiques \\ Integración regional en las Américas. Nuevas perspectivas socioecononómicas
}

\author{
Christine Zumello and Jean-Baptiste Velut
}

1 The $\mathrm{XX}^{\text {th }}$ century's last decade was characterized by an acceleration of the dynamics of regional integration all around the world. In most cases, regionalism appeared as an obvious strategic response to an intensified international competition in a more and more globalized economy. On the American continent, a great number of projects of regional integration were carried out under various forms, depending on their geographical impact (whether bilateral or multilateral), their ideological orientation (neoliberalism, Bolivarian Alternative, and so forth), the balance of power they implied (North-South or South-South), the degree of integration at stake (involving a sectoral agreement, common market or free trade area), and more generally on the "depth" of regional agreements - that is, their restrictive dimension and the decisional power of the supranational institutions involved.

2 Even though the polymorphism of regionalism(s) in the Americas excludes any kind of hasty conclusion regarding the costs and benefits of regional integration, it nevertheless enables us to question the stakes and socio-economic modalities of such processes. Does regional economic integration only involve the fusion of the productive and financial spheres? What political questions are considered as priorities? What fields are formally or officiously excluded from the dynamics of regionalism?

3 Regarding the modalities of regionalism, one must examine the structure of and role played by regional institutions, the latter being the most tangible incarnation of the political will involved in an integration project. For instance, the degree of application of a regional agreement, the functioning and actual power of supranational organisms or the budget allocated for a project often are indicative of the vigor of integration phenomena. In a similar way, the democratic nature of the decisional process - and 
more particularly the hierarchical structure and participative dimension of a project often has a direct impact on its legitimacy, and therefore on its perennity.

Aside from such institutional modalities, other forms of regionalism are also built off the beaten path of diplomacy. As opposed to official integration, there exists another kind of "real" integration based on migration flows, licit and illicit commercial exchanges, as well as investments. The convergences and divergences between both forms of integration also raise a number of questions regarding democracy, development and security. In what do the formal and informal dynamics that structure regionalism consist? Can we speak of different integration models on the American continent that perhaps synthesize the complex relationships between States, markets, regional institutions and citizens, in the same way as defining different "models of capitalism,"1 for example, have enabled us to schematize the political economy of States? Such modalities give rise to the economic and social consequences of regionalist policies, which may be seen as the fruit of the political capital invested by the architects of integration, or the ineluctable and unexpected backlash of such processes.

5 The first edition of the journal IdeAs will analyze the stakes and socio-economic modalities of regional integration in the Americas through various regional experiences, among which the NAFTA (North American Free Trade Agreement), CAFTA (Central America Free Trade Agreement) and SICA (Central American Integration System). This number will bring together research articles written by North American, French and Latin American researchers offering transversal perspectives on the intrinsic qualities of regionalism in the Americas. The aim of this study is, on the one hand, to establish a socio-economic appraisal of the last two decades of integration in the wake of the financial crisis whose propagation in the Western hemisphere was directly linked to the growing interdependence of the continent's economies. On the other hand, this edition will offer a prospective analysis of the main challenges the future architects of regionalist policies will have to face. Does the globalization of production lines make the regionalist model obsolete? What solutions will the governments on the American continent have to come up with in order to bridge the socio-economic gaps brought about by the various forms of regionalism? Will the future of regional integration involve the decline, the broadening or the deepening of such processes?

6 This edition opens with an article by Sherrie Baver, who examines the environmental stakes of regional integration in North America, and more precisely the links between free trade and environmental protection in the NAFTA experience. From an institutional viewpoint, the author analyzes the impact of the measures carried out by NAFTA on the implementation of environmental reforms in Mexico. The author also questions the historical precedent created by North American environmental institutions and their capacity to bring about a long-term reorientation of the American free trade model towards a more ecological future.

7 Josette Altmann Borbón adopts a more global approach to integration phenomena in Central America by concentrating on the stakes and limits of regionalism, along with its resilience in the face of globalization. She presents an assessment of the regionalization process over the last three decades and underlines the social and political challenges that Central American countries must take up so as to meet their peoples' democratic and environmental aspirations. Among other paradoxes, failures and shortcomings of Central American regionalism, she analyzes the ongoing conflicts 
between the various models of integration (North-South, South-South) prevailing in the area, the lack of political will of decision makers and the weakness of regional institutions.

Helen Chang compares North American and Central American integration experiences through an econometric analysis of the consequences of free trade on the synchronization of economic cycles. Her study serves a double purpose. First of all, it attempts to evaluate the degree of dependence of Latin American economies on the United States. Indeed, even though macroeconomic synchronization tends to reduce the volatility of developing countries, it may also lead to spillover effects that will increase their instability in times of crisis. Secondly, the author evaluates the different possible solutions to this dilemma by measuring the degree of coordination of the monetary and budgetary policies adopted by the members of NAFTA on the one hand, and CAFTA on the other.

9 Jean-Baptiste Velut also combines diagnosis and medication administration in a study of the consequences of NAFTA on Mexican economy fifteen years after the agreement's coming into effect. The author presents an analysis of the evolution of Mexican trade flows, investment and social indicators, in which he examines the imperfections of the North American regional model. He underlines the paradoxes of North American integration, and more specifically the conflicts between NAFTA's institutional modalities and strictly productive logic on the one hand, and on the other the social realities of North American integration and the limits of the agreement regarding the latter.

10 Such tensions may also be found at the heart of Fanny Lauby's work, which analyzes the characteristics of Mexican immigration to the United States during the post-NAFTA period. NAFTA was not able to meet the expectations of North American decision makers and curb the flow of immigrants heading North. This failure does not only result from the absence of any kind of migration clause in the agreement, but also from the militarization of the Mexican-American border, which paradoxically brought about the durability of illegal immigration. The author conceptualizes the emergence of a kind of informal regionalism fuelled by the immigration flows to the North and the money transferred by the immigrants back to the South. She analyzes the characteristics of this system parallel to NAFTA's institutional process, along with the stakes involved regarding the U.S.-Mexico partnership.

11 This collection of works derived from various academic traditions reveals the strengths and weaknesses of the processes of regional integration. It opens up new perspectives and raises many questions concerning the future of regionalisms in the Americas, the future successes of which shall necessarily imply a redefinition of the modalities of integration that would also take into account the social and environmental imperatives of the American continent. 


\section{NOTES}

1. Peter A. Hall \& David Soskice (eds.), Varieties of Capitalism: the Institutional Foundations of Comparative Advantage, Oxford: OUP, 2001.

\section{AUTHORS}

\section{CHRISTINE ZUMELLO}

Christine Zumello est maître de conférences en civilisation américaine à l'Université de la Sorbonne Nouvelle-Paris 3. Elle travaille plus particulièrement sur les institutions politiques américaines et les questions financières. Elle est membre du CERVEPAS, Centre de Recherche sur la Vie Economique dans les Pays Anglo-Saxons (EA 3960).

\section{JEAN-BAPTISTE VELUT}

Jean-Baptiste Velut est maître de Conférences en Civilisation Américaine à l'Université Sorbonne Nouvelle - Paris III. jean-baptiste.velut@univ-paris3.fr 